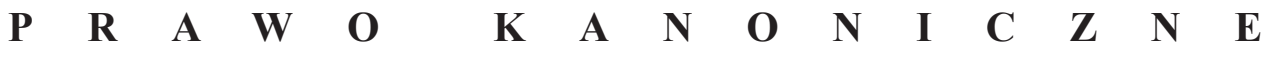

ROCZNIKI NAUK PRAWNYCH

Tom XXIX, numer $4-2019$

DOI: http://dx.doi.org/10.18290/rnp.2019.29.4-10

JUSTYNA KRZYWKOWSKA

\section{ZDOLNOŚĆ ŚWIADKÓW DO SKŁADANIA ZEZNAŃ PRZED SĄDAMI KOŚCIELNYMI}

Ważnym środkiem dowodowym $\mathrm{w}$ procesach przed sądem kościelnym są świadkowie. Obowiązkiem świadków jest szczere i zgodne z rzeczywistym stanem rzeczy przedstawianie faktów. Świadkowie wzywając imienia Boga przyrzekają mówić prawdę. Czynnikiem potwierdzającym prawdomówność świadków jest dobre świadectwo wiarygodności moralnej, tzw. świadectwo kwalifikacyjne ${ }^{1}$, jak również odpowiedzialność kanoniczna za składanie fałszywych zeznań (KPK/83, kan. $1572,1^{\circ}$ ). Z kolei czynnikiem negatywnym w odniesieniu do prawdomówności jest chęć osiągnięcia własnych korzyści w zamian za fałszywe zeznania ${ }^{2}$. Świadkiem może być każda osoba bez względu na płeć, jeśli wyraźnie nie została wyłączona przez prawo kanoniczne (KPK/83, kan. 1549). Świadków wskazują nie tylko strony procesowe, ale również takie uprawnienie posiada biorący udział w procesie obrońca węzła lub rzecznik sprawiedliwości (KPK/83, kan. 1434), jak również sędzia z urzędu, kiedy wymaga tego dobro publiczne (KPK/83, kan. 1452) ${ }^{3}$.

Dr Justyna Krzywkowska - adiunkt w Katedrze Teorii i Historii Prawa, Wydział Prawa i Administracji, Uniwersytet Warmińsko-Mazurski w Olsztynie, ul. Warszawska 98, 10-702 Olsztyn; e-mail: justyna.krzywkowska@uwm.edu.pl; https://orcid.org/0000-0002-0667-6453

${ }^{1}$ Codex Iuris Canonici auctoritate Ioannis Pauli PP. II promulgatus (25.01.1983), AAS 75 (1983), pars. II, s. 1-317; tekst polski: Kodeks Prawa Kanonicznego, przekład polski zatwierdzony przez Konferencję Episkopatu, Poznań: Pallottinum 1984 [dalej cyt.: KPK/83]. Zob. R. WóJCICKI, Znaczenie świadectw kwalifikacyjnych $w$ procesie o stwierdzenie nieważności matzeństwa, [w:] Dowodzenie w procesach kościelnych, red. J. Krzywkowska, R. Sztychmiler, Olsztyn: Zakład Poligraficzny Uniwersytetu Warmińsko-Mazurskiego w Olsztynie 2014, s. 161-170.

${ }^{2}$ M.A. Myrcha, Dowód ze świadków w procesie kanonicznym, Lublin: Towarzystwo Naukowe KUL 1936, s. 20-35.

${ }^{3}$ Z. Grocholewski, Struktura etapu dowodowego procesu, [w:] Plenitudo legis dilectio. Ksiega pamiątkowa dedykowana prof. dr. hab. Bronisławowi Z. Zubertowi OFM z okazji 65. rocznicy urodzin, red. A. Dębiński, E. Szczot, Lublin: Redakcja Wydawnictw KUL 2000, s. 361-363. 
W niniejszym artykule ukazane zostanie znaczenie zeznań świadków w procesach o stwierdzenie nieważności małżeństwa, które toczą się przed sądami kościelnymi. Wskazane będą normy proceduralne dotyczące świadków, ich zatwierdzania i wykluczania, jak również wymogi prawne stawiane osobom składającym zeznania na temat małżeństwa stron procesowych. Często prawdy o małżeństwie, jego nieważności, nie można udowodnić za pomocą dokumentu, wówczas ustalenie prawdy jest możliwe za pomocą zeznań świadków.

\section{TESTIS UNUS, TESTIS NULLUS}

Obok świadectwa ślubu kościelnego i różnych dokumentów publicznych lub prywatnych lista świadków stanowi załącznik do skargi powodowej, choć bywa, że dane świadków zawarte są bezpośrednio w treści skargi. Obecnie ze względu na $\mathrm{RODO}^{4}$ lepszym rozwiązaniem jest przedstawienie danych adresowych i kontaktowych do świadków w formie załącznika do skargi powodowej. Należy pamiętać, na co zwracają uwagę też niektórzy wikariusze sądowi, że pod listą świadków powinien widnieć podpis strony procesowej bądź jej pełnomocnika. Wskazując świadków należy bowiem podać ich dokładne adresy, kim są dla stron i co mogą powiedzieć o stronach $\mathrm{w}$ okresie przedślubnym, ślubnym i poślubnym ${ }^{5}$.

Jak stanowi łacińska paremia testis unus, testis nullus ${ }^{6}$, strona powodowa powinna wskazać przynajmniej dwóch świadków prywatnych (zwykłych). Świadków zalicza się do tzw. dowodów osobowych, bowiem źródłem pochodzenia informacji jest tu osoba ludzka. Fundamentalnymi przymiotami tego środka dowodowego powinny być wiedza oraz szczerość. Świadkowie podają własne spostrzeżenia na temat poznanego zdarzenia. Świadkowie bezpośredni widzieli to zdarzenie na własne oczy lub o danym fakcie słyszeli na własne uszy. Natomiast świadkowie pośredni wiedzą o danym fakcie ze słyszenia od innych. Ponadto świadków dzieli się na publicznych (kwalifikowanych, urzędowych) i prywatnych. Pierwszy rodzaj świadków to osoby pełniące urząd publiczny gdy świadczą o czynnościach dokonanych przez siebie, zaś pozostali są świadkami prywatnymi. Jak czytamy w znowelizowanym przez papieża Franciszka kan. 1678 § 1 Kodeksu Prawa Kanonicznego, „zeznanie tylko jednego świadka może mieć pełną wartość dowodową,

\footnotetext{
${ }^{4}$ Rozporządzenie Parlamentu Europejskiego i Rady UE 2016/679 z dnia 27 kwietnia 2016 r. w sprawie ochrony osób fizycznych w związku z przetwarzaniem danych osobowych i w sprawie swobodnego przepływu takich danych, Dz. Urz. EU L Nr 119, s. 1-88.

${ }^{5}$ T. Pawluk, Prawo kanoniczne wedlug Kodeksu Jana Pawła II, t. IV: Doczesne dobra Kościota. Sankcje w Kościele. Procesy, Olszyn: Warmińskie Wydawnictwo Diecezjalne 1990, s. 234-235.

${ }^{6}$ Tzn. jeden świadek, żaden świadek.
} 
jeżeli składa je świadek kwalifikowany, który zeznaje o sprawach dokonanych w związku z pełnieniem urzędu albo sugerują to okoliczności dotyczące rzeczy lub osób" "7.

Dostarczanie dowodów w sprawie o nieważność małżeństwa należy do stron - małżonków (KPK/83, kan. 1526 § 1). Strona powodowa może uzupełnić listę świadków, którą dołączyła do skargi powodowej i zgłosić dodatkowych świadków $\mathrm{w}$ trakcie przesłuchania, jak również po zapoznaniu się z materiałem dowodowym w czasie publikacji akt (KPK/83, kan. 1598 § 2). Strona pozwana ma możliwość zgłoszenia świadków w piśmie składanym w odpowiedzi na przyjęcie skargi powodowej, podczas składania zeznań i w czasie publikacji akt. Oprócz tego istnieje możliwość uzupełnienia dowodów z urzędu przez sędziego (KPK/83, kan. 1452). Ma to miejsce np. w sytuacji nieobecności strony pozwanej i wskazaniu świadków jedynie ze strony powodowej. Zdarzają się także sytuacje, w których już po zamknięciu postępowaniu dowodowego nastąpi powołanie świadka, ponieważ wcześniej miał przeszkodę stawić się przed sądem kościelnym (KPK/83, kan. 1600). W sytuacji nadzwyczajnej, gdy np. ciężka choroba świadka przemawia za wcześniejszym zebraniem materiału dowodowego (KPK/83, kan. 1529), może on złożyć zeznania zanim zostaną przesłuchane strony procesowe. Listę zatwierdzonych i dopuszczonych do złożenia zeznań świadków sędzia ogłasza w formie dekretu podawanego do wiadomości stronom procesowym i powinien to uczynić jeszcze przed rozpoczęciem przesłuchania świadków (KPK/83, kan. 1554). Jeżeli sędzia z ważnego powodu uczyni to później, wówczas dekretem - podając słuszną przyczynę - winien poinformować o tym strony. Ponadto kan. 1553 KPK/83 pozwala sędziemu na ograniczenie liczby świadków.

\section{PYTANIA DO ŚWIADKÓW I SPOSÓB ICH PRZESŁUCHANIA}

Świadków przeważnie przesłuchuje audytor - osoba duchowna lub świecka odznaczająca się dobrymi obyczajami, roztropnością i wiedzą (kan. $1428 \S 2$ ). Powołanie audytora jest fakultatywne, bowiem nic nie stoi na przeszkodzie, aby zarówno strony procesowe, jak i świadków przesłuchiwał przewodniczący trybunału kolegialnego. Świadek przybywa do sądu po wcześniejszym otrzymaniu wezwania. W niektórych sądach istnieje praktyka, że audytor zanim wyśle wezwanie sądowe,

\footnotetext{
${ }^{7}$ Franciscus PP., Motu proprio Mitis Iudex Dominus Iesus «quibus canones codicis iuris canonici de causis ad matrimonii nullitatem declarandam reformantur» (15.08.2015); tekst polski: FranCISZEK, List apostolski motu proprio „Mitis Iudex Dominus Iesus” reformujacy kanony Kodeksu Prawa Kanonicznego dotyczace spraw o orzeczenie nieważności matżeństwa, Tarnów: Wydawnictwo Diecezji Tarnowskiej Biblos 2015, kan. 1678 § 1.
} 
dzwoni do świadka i ustala z nim możliwy termin przybycia do sądu kościelnego. Obecność świadka w sądzie wynika z jego dobrej woli, jak również zobowiązania moralnego do pomocy sędziom w ujawnieniu prawdy obiektywnej o konkretnym małżeństwie (KPK/83, kan. 1557). Prawo kanoniczne nie zna przymusowego stawiennictwa w sądzie kościelnym (KPK/83, kan. 1528) ${ }^{8}$.

Zanim audytor (przewodniczący, sędzia) odbierze przysięgę zobowiązującą świadka do mówienia prawdy, powinien zweryfikować za pomocą dokumentu tożsamość zeznającego. Osoba przesłuchująca powinna być zapoznana zarówno ze świadectwem moralności świadka, jak i dotychczas zebranym materiałem dowodowym: skargą powodową, odpowiedzią na skargę powodową, zeznaniami stron czy dokumentami znajdującymi się już w aktach sprawy. Nieodpowiedzialne jest niezapoznanie się z ich treścią, gdy znajdują się w siedzibie trybunału. Przeważnie dla świadków wizyta w sądzie kościelnym jest wielkim przeżyciem, a ponadto opowiadanie o sprawach osobistych innych ludzi powoduje stres. Dlatego duże znaczenie ma zachowanie audytora wobec świadka. Już Kodeks Prawa Kanonicznego z 1917 r. ${ }^{9}$ w kan. 1775 zakazywał sędziemu stawiania niejasnych pytań (KPK/83, kan. 1564). Samo zaprotokołowanie odpowiedzi świadka na pytania otrzymane od przewodniczącego trybunału kolegialnego, obrońcy węzła małżeńskiego i adwokata kościelnego, o ile występuje w sprawie, w sytuacji gdy świadek jest małomówny, niewiele wniesie do procesu. Dobry audytor widząc problemy świadka z wysłowieniem się, jego zdenerwowanie, powinien pomóc mu poprzez zadawanie dodatkowych pytań. Jako przykład można wskazać pytanie: czy strony, zdaniem świadka, znały naukę Kościoła o małżeństwie? Jest to pytanie tak ogólne, że świadek zazwyczaj odpowiada znały bądź nie znały. Najpierw trzeba zweryfikować co świadek rozumie przez naukę Kościoła o małżeństwie, czy rozmawiał ze stronami na temat wierności, nierozerwalności, płodności małżeństwa, jaki

\footnotetext{
${ }^{8}$ Powodem odmowy złożenia zeznań przez świadków wskazanych przez strony jest przede wszystkim niechęć opowiedzenia się po jednej ze stron. Ważne jest zatem, aby wezwanie sądowe zawierało pouczenie świadka, że jego obecność pomoże sędziom poznać prawdę o małżeństwie stron. W sytuacji świadka katolika należy zaznaczyć, że jego stawiennictwo jest obowiązkiem moralnym, ponieważ zawarte małżeństwo stanowi dobro całego Kościoła, o które każdy ochrzczony powinien troszczyć się. Kolejnym powodem odmowy zeznań jest także brak wiedzy na temat małżeństwa stron. Zdarza się, że strona podaje kilku świadków, ponieważ taki jest wymóg prawa kanonicznego, stąd ważny jest dokładny opis, na jaką okoliczność świadek może zeznawać. Są bowiem powoływani świadkowie, którzy nie utrzymywali kontaktu ze stronami przed ślubem, a nawet ich nie znali, dopiero wiele lat po ślubie nawiązali kontakt w pracy lub innym miejscu z jednym ze współmałżonków. Tacy świadkowie niewiele wniosą do procesu. Warto, aby sądy weryfikowały przydatność świadków zwłaszcza podczas składania zeznań przez strony procesowe.

${ }^{9}$ Codex Iuris Canonici, Pii X Pontificis Maximi iussu digestus, Benedicti Papae XV auctoritate promulgatus (27.05.1917), AAS 9 (1917), pars II, s. 3-521 [dalej cyt.: KPK/17].
} 
był w tamtym czasie stosunek stron do religii i Kościoła, jakie głosiły poglądy na temat aborcji, antykoncepcji. Dodatkowe pytania, których nie ma zapisanych na liście, z pewnością pozwolą świadkowi lepiej ustosunkować się do omawianej kwestii. Nieścisłość zeznań sędzia powinien wyeliminować w trakcie przesłuchania. Jeżeli świadek cytuje skargę powodową, sędzia powinien dopytać się czy strona nie sugerowała świadkowi co ma zeznawać.

Dużym problemem w sądownictwie kościelnym jest wykonywanie rekwizycji. Sąd kościelny otrzymując prośbę z innego sądu o przesłuchanie świadka dostaje przeważnie pismo przewodnie wraz z listą pytań. Rzadko załączana jest kopia skargi powodowej. Wówczas audytor powinien szczególnie zwrócić uwagę na odpowiedzi świadka, aby nie były one zbyt lakoniczne. Bywa niestety, że sąd prowadzący daną sprawę otrzymuje protokół zeznań świadka z dużą liczbą odpowiedzi ograniczających się do „tak”, „nie”. Praktyka sądowa i prawo kanoniczne dopuszczają przesłuchanie świadka poza siedzibą sądu (KPK/83, kan. 1558 § 3), np. w kancelarii parafialnej. Takie przypadki należy ograniczać do minimum, jeżeli sędzią delegowanym nie jest kanonista, często bowiem jakość otrzymywanych protokołów zeznań jest słaba. Warto wówczas rozważyć, czy nie byłoby dobrze, aby także w terenie audytor osobiście przesłuchiwał świadków. Niezbędne są szkolenia dla księży dziekanów bądź oddelegowanych duszpasterzy z danego dekanatu w zakresie prawidłowego przesłuchiwania stron i świadków ${ }^{10}$.

Pytania dla świadków dzielą się na dwie grupy: pytania ogólne oraz pytania szczegółowe. Pierwsza grupa pytań dotyczy następujących danych personalnych: imię i nazwisko, imiona rodziców, data i miejsce urodzenia, seria i numer dowodu osobistego, wyznanie, wykształcenie, zawód, miejsce zamieszkania. Następnie osoba przesłuchująca bada stan religijności świadka, tzn., czy świadek spełnia praktyki religijne i kiedy był ostatni raz u spowiedzi i Komunii św. Pytania o to są ważne dla weryfikacji prawdomówności świadka. Świadek mający naganne świadectwo kwalifikacje, a który opowiada o coniedzielnym udziale we Mszy św. nie jest świadkiem wiarygodnym. Następnie audytor (sędzia) bada czy ktoś pouczał świadka, jak i co powinien zeznawać w niniejszej sprawie. Dalej zadawane są pytania szczegółowe dotyczące środowiska rodzinnego obu stron procesowych, kojarzenia się małżeństwa, przygotowań do ślubu i wesela, okresu poślubnego, aż po czas rozpadu związku i uzyskania rozwodu. Ważne jest dopytywanie się świadka o źródło podawanych informacji oraz termin ich uzyskania (KPK/83, kan. 1563).

${ }^{10}$ Dobrym rozwiązaniem była propozycja R. Sztychmilera, ówczesnego oficjała Metropolitalnego Sądu Archidiecezji Warmińskiej w Olsztynie, dotycząca ustanowienia terenowych sędziów delegowanych, którzy po specjalistycznym szkoleniu sądowym są przygotowani do właściwego przeprowadzania przesłuchań. Zob. R. SzTYCHMILER, Rekwizycje sądowe, „Biuletyn Stowarzyszenia Kanonistów Polskich" 17 (2004), s. 72. 
Zarówno adwokat, jak i obrońca węzła małżeńskiego nie mogą sugestywnie oddziaływać na sędziego, ponieważ nie przysługuje im prawo bezpośredniego stawiania pytań świadkowi, tylko za pośrednictwem sędziego, który może dowolnie je zmienić i podać w formie niesugestywnej. Przesłuchania świadków odbywają się oddzielnie i bez obecności stron. Podczas przesłuchania powinien być obecny obowiązkowo notariusz kościelny (KPK/83, kan. 1561). Nie może mieć miejsca sytuacja, że świadek podpisuje protokół zeznań, który zawiera informację o osobach obecnych w czasie przesłuchania, a wymienionych osób faktycznie nie ma. Takie zachowanie godzi w dobre imię Kościoła. Jak pokazuje praktyka sądowa, istnieją audytorzy, dla których wygodniejsze jest jednoczesne zapisywanie odpowiedzi świadka niż dyktowanie treści notariuszowi. Jednak wygoda nie może być ważniejsza niż przepis prawa kanonicznego. Świadek słysząc to, co dyktuje audytor, jednocześnie może kontrolować czy został dobrze zrozumiany i jego wypowiedź została poprawnie zapisana. Coraz częściej osoby zeznające w sądach kościelnych posiadają informacje na temat przebiegu procesu kanonicznego, chociażby ze stron internetowych adwokatów kościelnych, i wówczas nieprzestrzeganie przepisów proceduralnych może spowodować wątpliwości moralne na temat rzetelności wydanego wyroku.

Notariusz nie spełnia czynności jurysdykcyjnych, ponieważ nie posiada żadnej władzy, ale jest świadkiem urzędowym i jego podpis nadaje protokołowi zeznań status dokumentu publicznego ${ }^{11}$. Jak zaznaczył papież Jan Paweł II w przemówieniu do Roty Rzymskiej z dnia 4 lutego 1980 r., proces o nieważność małżeństwa w oparciu o przepisy prawa kanonicznego ma ukazać zgodną z rzeczywistością prawdę o małżeństwie stron procesowych ${ }^{12}$.

Prawo kanoniczne nakazuje dokładne spisywanie zeznań świadka oraz ich odczytanie po przesłuchaniu (KPK/17, kan. 1778, kan. 1780). Zeznania powinny odzwierciedlić myśl wyrażoną przez świadka. Od przesłuchującego wymaga się nie tylko znajomości przepisów prawnych, ale także roztropności i znajomości podstaw psychologii.

Zgodnie z kan. $1471 \mathrm{KPK} / 83$ istnieje możliwość skorzystania z pomocy zaprzysiężonego tłumacza ${ }^{13}$. Ustawodawca przewidział bowiem ewentualność składania zeznań przez osobę w języku nieznanym sędziemu (audytorowi).

${ }^{11}$ T. PIERonek, Normy ogólne kanonicznego procesu sądowego, cz. I, Warszawa: Akademia Teologii Katolickiej 1970, s. 129-133.

${ }^{12}$ Ioannes Paulus PP. II, Allocutio ad Tribunalis Sacrae Romanae Rotae Decanum, Praelatos Auditores, Officiales et Advocatos, novo litibus iudicandis ineunte anno: de veritate iustitia matre (4.02.1980), AAS 72 (1980), s. 172-178. Także A. Brzemia-BonAreK, Metody odkrycia prawdy procesowej przez sędziego w kanonicznym procesie matżéski, „Analecta Cracoviensia” 48 (2016), s. 314, doi: http://dx.doi.org/10.15633/acr.2029

${ }^{13}$ Zob. Pontificium Consilium de Legum Textibus, Dignitas connubii. Instructio servanda a tribunalibus dioecesanis et interdioecesanis in pertractantibus causis nullitatis matrimonii (25.01.2005), Città del Vaticano [b.w.] 2005, art. 172. 
Protokół zeznań po odczytaniu świadkowi powinien być przez niego podpisany. Jeśli świadek odmawia złożenia podpisu, wówczas należy ten fakt odnotować oraz zaznaczyć, że po zakończeniu przesłuchania protokół został świadkowi odczytany, a on nie może lub nie chce go podpisać (KPK/83, kan. 1473). Bez wątpienia sprawa przesłuchania świadków należy do najtrudniejszych etapów w postępowaniu dowodowym.

\section{MOŻLIWOŚCI WERYFIKACJI ZEZNAŃ ŚWIADKÓW}

Kodeks zabezpiecza prawa stron i sędziego do weryfikacji zeznań świadków. Każda ze stron procesowych biorąca udział w procesie otrzymuje powiadomienie o dekrecie zatwierdzającym świadków, w którym znajduje się stosowna informacja, że wraz z podaniem uzasadnienia świadek może zostać na wniosek strony wykluczony z procesu. Istnieją sytuacje, że strona słusznie podważa zasadność zatwierdzenia świadka:

„W odpowiedzi na powiadomienie sądowe o wykazie zatwierdzonych świadków w sprawie o nieważność małżeństwa [...] zgłaszam zastrzeżenie wobec świadka [...] i proszę o jego wykluczenie. Jest to mój były szwagier, który oszukał i okradł moją rodzinę. Ma on mnóstwo pozakładanych spraw w związku ze swoimi oszustwami wobec innych osób i firm. Jest to osoba, której zależy wyłącznie na pieniądzach i tego nie ukrywa. Rodzina, dzieci niestety nie mają w jego życiu większego znaczenia, o ile mają jakiekolwiek. Zeznania tego świadka mogą zniekształcić rzeczywistość dotyczącą mojego małżeństwa. Gdyby Sąd postanowił jednak - mimo moich zastrzeżeń - przesłuchać świadka [...], to analizując jego zeznania proszę wziąć pod uwagę moją opinię na temat jego prawdomówności”.

Także sędzia z urzędu może wyłączyć świadka ze względu na brak kwalifikacji wymaganych przez prawo. Z prawa naturalnego za świadków niezdatnych uważa się: niewidomych, jeśli chodzi o fakty poznane za pomocą wzroku oraz głuchych, jeśli chodzi o fakty poznane za pomocą słuchu. Niewidomy może zeznawać co do zdarzeń mających miejsce przed utratą wzroku. Głuchoniemi od urodzenia są pozbawieni dostatecznego rozeznania, dlatego odmawia się im możliwości składania zeznań. Na zdatność kandydata na świadka w procesie kanonicznym wpływa zatem jego zdolność do spostrzeżeń zmysłowych. Jeżeli dany świadek nie może z określonych kodeksowych przyczyn zeznawać, wówczas zostaje on wykluczony $z$ listy świadków lub nie zostaje zatwierdzony w dekrecie powołujących świadków.

Za niezdolnych do złożenia zeznań prawo kanoniczne uznaje również tych, którzy „występują w sądzie w imieniu stron, sędziego i jego asystentów, adwokata oraz innych, którzy pomagają lub pomagali stronom w tej sprawie" (KPK/83, kan. 
$1550 \S 2,2^{\circ}$ ). Jednak, jak wskazują przedstawiciele doktryny prawa kanonicznego, jeżeli adwokat kościelny pomógł stronie jedynie na etapie przedprocesowym, zanim skarga powodowa została złożona do sądu kościelnego, wówczas może być on dopuszczony jako świadek do złożenia zeznań ${ }^{14}$.

Kolejną grupą świadków niezdolnych są „,duchowni, w odniesieniu do tego, co im przekazano z racji sprawowania świętej posługi; urzędnicy państwowi, lekarze, położne, adwokaci, notariusze i inni zobowiązani do zachowania tajemnicy urzędowej także z racji udzielania porady, w zakresie spraw objętych tą tajemnicą; ci, którzy ze swojego zeznania obawiają się dla siebie lub współmałżonka albo dla bliskich krewnych lub powinowatych zniesławienia, niebezpiecznych przykrości lub innego poważnego zła" (KPK/83, kan. 1548 § 2, $1^{\circ}$, kan. $1550 \S 2,2^{\circ}$ ).

Strona procesowa wskazując konkretne osoby na świadków musi brać pod uwagę to, czy mają one właściwości umysłowe wymagane do dokładnego poznania danego faktu, bowiem istotna jest zdolność rozumowania. Dlatego osoby całkowicie pozbawione rozumu (chorzy psychicznie, dzieci) nie mogą zeznawać w sądzie ${ }^{15}$. Rozumowanie, wiek, pamięć, wyobraźnia to wszystko wpływa na treść złożonych zeznań. Dlatego „nie należy dopuszczać do składania zeznań małoletnich poniżej czternastego roku życia i upośledzonych umysłowo; mogą być jednak przesłuchani na mocy dekretu sędziego, w którym uzasadni się taką potrzebę" (KPK/83, kan. 1550 § 1). Często bywa tak, że od dnia ślubu kościelnego minęło kilkanaście lat - w takich przypadkach błędne wspomnienia bywają zazwyczaj skutkiem upływu dłuższego czasu od chwili wystąpienia danego wydarzenia.

Nadzwyczajną formą przesłuchania świadków jest konfrontacja, o której stanowi kan. $1560 \mathrm{KPK} / 83$. Jest ona jednak rzadko stosowana w polskiej praktyce.

Obie strony procesowe mają możliwość zapoznania się z aktami sprawami, czyli m.in. z treścią zeznań świadków. Publikacja akt stanowi bardzo ważny element procedury kanonicznej. Nikt lepiej od stron procesowych nie wie, jak faktycznie wyglądało ich życie przedmałżeńskie i małżeńskie. Możliwość zapoznania się z treścią złożonych przez świadków zeznań pozwala stronie powodowej i pozwanej na zweryfikowanie ich treści pod względem wiarygodności i rzetelności. Błędem strony procesowej jest rezygnacja z publikacji akt.

Bardzo ważną rolę na etapie publikacji akt odgrywa adwokat kościelny, bowiem jest on w stanie ocenić, na ile zgromadzony materiał dowodowy jest wystarczający

\footnotetext{
${ }^{14}$ L. Del Amo, Dowody, [w:] Codex Iuris Canonici. Kodeks Prawa Kanonicznego. Komentarz. Powszechne i partykularne ustawodawstwo Kościoła katolickiego. Podstawowe akty polskiego prawa wyznaniowego, red. P. Majer, edycja polska na podstawie wydania hiszpańskiego, Kraków: Lex a Wolters Kluwer business 2011, s. 1167.

${ }^{15}$ Por. KPK/17, kan. $1757 \S 1$ - od składania zeznań wykluczone są osoby posiadające używanie rozumu $\mathrm{W}$ stopniu niedostatecznym.
} 
na uzyskanie przez sędziów moralnej pewności niezbędnej do wydania wyroku. W sytuacji wątpliwości odnośnie wystarczalności dowodów może zaproponować stronie wskazanie dodatkowych świadków. Strona procesowa, chociaż czyta akta w sposób emocjonalny i głównie zwraca uwagę co na jej temat powiedzieli świadkowie (nawet wówczas, gdy rozpatrywany tytuł nieważności dotyczy tylko jej współmałżonka), to jednak jest w stanie zweryfikować czy zeznania są szczere i wyczerpujące ${ }^{16}$. Jeżeli dostrzeże informacje nieprawdziwe, powinna złożyć na piśmie swoje uwagi, o czym informowana jest już w powiadomieniu o dekrecie publikacji akt. Sędziowie wyrokujący w konkretnej sprawie końcową decyzję będą podejmować jedynie na podstawie zgromadzonego materiału dowodowego.

Do sędziego należy przeprowadzenie dowodu oraz ocena wiarygodności zeznań świadka. Dowód, aby mógł dostarczyć sędziemu pewności moralnej ${ }^{17}$ musi być jasny, pewny i odnosić się do sprawy, która jest przedmiotem postępowania sądowego. Stąd niezwykle ważne bywa dokonanie opisu dziwnego zachowania świadka podczas przesłuchania i przekazanie tej informacji do wiadomości sędziów wotujących (KPK/83, kan. 1568). Sprawy o nieważność małżeństwa związane są ze stanem osób. Właśnie w sprawach stanu bardzo często jedynymi świadkami są osoby najbliższe. Zdarza się, że najbliżsi chcąc pomóc synowi bądź córce w uzyskaniu pozytywnego wyroku w sprawie o nieważność małżeństwa, błędnie interpretują zaobserwowany przez siebie sposób funkcjonowania związku małżeńskiego bądź celowo pomijają albo przerysowują pewne fakty. Znane są przypadki, gdzie po pewnym czasie np. matka powoda przesyła do sądu kościelnego pismo informujące, że w zeznaniach koloryzowała i na piśmie przedstawia faktyczny opis przebiegu małżeństwa stron procesowych.

\section{ODPOWIEDZIALNOŚĆ KANONICZNA ZA SKŁADANIE FAŁSZYWYCH ZEZNAŃ}

Prawo Boże stanowi: „Nie mów fałszywego świadectwa przeciw bliźniemu swemu". Można zatem domniemywać, że moralność chrześcijańska sprzyja prawdomówności. Zanim świadek zostanie przesłuchany, odbierana jest od niego przysięga zobowiązująca do składania szczerych i prawdziwych zeznań. Zdecy-

\footnotetext{
${ }^{16} \mathrm{~Np} . \mathrm{w}$ jednej ze spraw po publikacji akt powódka napisała: „Bardzo mnie zaskoczyły zeznania matki pozwanego. Osoba, która uważa się za gorliwego katolika, za kogoś kto żyje zgodnie z kanonami Kościoła opowiada takie bzdury".

${ }^{17}$ Wewnętrzne przekonanie sędziego o prawdziwości zebranego materiału dowodowego.
} 
dowana większość świadków zdaje sobie sprawę z powagi tej czynności ${ }^{18}$. Fakt złożenia lub brak przysięgi powinien być odnotowany w aktach sprawy. Przysięga zobowiązuje świadka nie tylko do składania szczerych zeznań, ale również do zachowania tajemnicy odnośnie zadawanych pytań i udzielanych odpowiedzi aż do zakończenia procesu o nieważność małżeństwa. W sytuacji braku zgody na złożenie przysięgi świadek jest przesłuchiwany, ale jego zeznania stają się mniej wiarygodne. Jeżeli świadkiem jest osobą niewierząca, w rocie przysięgi pomija się wezwanie Boga wszechmogącego w Trójcy jedynego. Przysięga może być składana albo przed zeznaniami, albo tylko po zeznaniu, bądź istnieje możliwość złożenia przysięgi przed i po zeznaniu. Dla podkreślenia wiarygodności osoby zeznającej wystarczy złożenie jednej przysięgi.

Za składanie fałszywych zeznań grozi sankcja moralna i kanoniczna ${ }^{19}$. Stwierdzone krzywoprzysięstwo jest przestępstwem kościelnym i może być podstawą do wymierzenia odpowiedniej (sprawiedliwej) kary, która nie została wprost określona przez ustawodawcę. Racją karania za ten rodzaj zachowania jest ochrona czci należnej Bogu i religijnego zaufania wiernych do siebie ${ }^{20}$.

\section{SĘDZIOWSKA OCENA ZEZNAŃ ŚWIADKÓW}

Zadaniem sędziego jest ocenić wartość zeznań wszystkich świadków. Należy mieć na uwadze, że do sądu kościelnego skargi o nieważność małżeństwa wpływają też wiele lat po ślubie, a wówczas może zaistnieć problem ze wskazaniem świadków znających strony jeszcze sprzed okresu przedmałżeńskiego. Do wydania wyroku stwierdzającego nieważność małżeństwa sędzia musi posiąść pewność moralną. Kodeks Prawa Kanonicznego podkreśla zasadę swobodnej oceny sędziowskiej, jednak sędzia nie może stosować samowoli przy ocenie zeznań świadków ${ }^{21}$.

Sędzia musi wziąć pod uwagę czy świadkowie zeznają na podstawie własnej wiedzy, widzenia, słyszenia czy na podstawie rozgłosu bądź przypuszczenia. Przy ocenie zeznań ma znaczenie kwestia, od kogo świadek usłyszał daną informację,

\footnotetext{
${ }^{18} \mathrm{KPK} / 83$, kan. 1562. Świadek musi być pouczony przez sędziego o znaczeniu złożonej przysięgi wiarygodności. Por. KPK/17, kan. $1755 \S 3$ oraz kan. $1743 \S 3$.

${ }^{19} \mathrm{KPK} / 83$, kan. 1368: „Kto stwierdzając lub przyrzekając coś wobec władzy kościelnej dopuszcza się krzywoprzysięstwa, powinien być ukarany sprawiedliwą karą".

${ }^{20}$ P.M. GaJdA, Sankcje karne w Kościele w świetle Kodeksu Prawa Kanonicznego Jana Pawła II oraz późniejszych uzupetnień i zmian. Studium kanoniczno-pastoralne, Tarnów: Wydawnictwo Diecezji Tarnowskiej Biblos 2008, s. 123-124.

${ }^{21}$ R. SzTYChMiLer, Ochrona praw człowieka w normach kanonicznego procesu spornego, Olsztyn: Wydawnictwo Uniwersytetu Warmińsko-Mazurskiego w Olsztynie 2003, s. 183-186.
} 
ilu świadków potwierdza daną wiadomość oraz w jakich okolicznościach i terminie świadek powziął konkretną informację (KPK/83, kan. 1572, $\left.2^{\circ}-4^{\circ}\right)$. Sędzia oceniając wartość dowodową zeznań świadka powinien wziąć pod uwagę, kim jest dany świadek, jaką cieszy się opinią u ludzi (KPK/83, kan. 1572, $\left.1^{\circ}\right)$. Na wiarygodność świadka wpływa także wiek, inteligencja, charakter, poziom religijności i moralności. Wartość dowodowa zeznań zależy także od relacji świadka ze stroną i stopnia pokrewieństwa $\mathrm{z}$ nią.

\section{PODSUMOWANIE}

Prawo kanoniczne określa moment rozpoczęcia postępowania dowodowego (w kan. 1516) oraz jego zamknięcia (w kan. 1599). Wśród kodeksowych kategorii środków dowodowych wymienione są: oświadczenia stron, dokumenty, świadkowie, biegli, wizja lokalna i oględziny sądowe oraz domniemanie sędziowskie. Dowód ze świadków w prawie procesowym odgrywa bardzo ważną rolę. To do sędziego należy dopuszczenie danej osoby do złożenia zeznań w charakterze świadka. $\mathrm{Z}$ jednej strony istnieje prawo stron do zgłaszania środków dowodowych, w tym świadków, z drugiej strony należy uwzględnić roztropność sędziego, ekonomikę procesu, a przede wszystkim potrzebę dotarcia do prawdy obiektywnej. Sędzia ma prawo niedopuszczenia do procesu świadka niewiarygodnego, jak również świadka, którego można uznać za nieużytecznego, bowiem nic nowego nie wniesie do sprawy niż to, co zostało już zaprotokołowane w aktach sprawy, a jego zgłoszenie przez stronę pozwaną ma jedynie opóźnić termin wydania wyroku. W zakresie właściwego doboru świadków należy podkreślić korzyść z występowania w procesach adwokatów kościelnych, którzy swoją fachową wiedzą doradzą stronie procesowej, którzy z proponowanych przez nią świadków są odpowiedni do złożenia zeznań $\mathrm{w}$ procesie kanonicznym ${ }^{22}$.

\section{BIBLIOGRAFIA}

\section{ŹRÓDŁA PRAWA}

Codex Iuris Canonici auctoritate Ioannis Pauli PP. II promulgatus (25.01.1983), AAS 75 (1983), pars II, s. 1-317; tekst polski: Kodeks Prawa Kanonicznego, przekład polski zatwierdzony przez Konferencję Episkopatu, Poznań: Pallottinum 1984.

22 J. KRZYwKowsKa, R. SZTYCHMILER, Adwokat w sprawach o nieważność matżeństwa. Rozwiązania ustawodawcze i ich stosowanie w sąach kościelnych (1983-2019), Olsztyn: Zakład Poligraficzny Uniwersytetu Warmińsko-Mazurskiego w Olsztynie 2018, s. 106-108. 
Codex Iuris Canonici, Pii X Pontificis Maximi iussu digestus, Benedicti Papae XV auctoritate promulgatus (27.05.1917), AAS 9 (1917), pars II, s. 3-521.

Franciscus PP., Motu proprio Mitis Iudex Dominus Iesus «quibus canones codicis iuris canonici de causis ad matrimonii nullitatem declarandam reformantur (15.08.2015); tekst polski: FrANCISZEK, List apostolski motu proprio „Mitis Iudex Dominus Iesus” reformujący kanony Kodeksu Prawa Kanonicznego dotyczące spraw o orzeczenie nieważności małżeństwa, Tarnów: Wydawnictwo Diecezji Tarnowskiej Biblos 2015.

IoAnnes Paulus PP. II, Allocutio ad Tribunalis Sacrae Romanae Rotae Decanum, Praelatos Auditores, Officiales et Advocatos, novo litibus iudicandis ineunte anno: de veritate iustitia matre (4.02.1980), AAS 72 (1980), s. 172-178.

Pontificium Consilium de Legum Textibus, Dignitas connubii. Instructio servanda a tribunalibus dioecesanis et interdioecesanis in pertractantibus causis nullitatis matrimonii (25.01.2005), Città del Vaticano: Libreria Editrice Vaticana 2005.

Rozporządzenie Parlamentu Europejskiego i Rady UE 2016/679 z dnia 27 kwietnia 2016 r. w sprawie ochrony osób fizycznych w związku z przetwarzaniem danych osobowych i w sprawie swobodnego przepływu takich danych, Dz. Urz. EU L Nr 119, s. 1-88.

\section{LITERATURA}

BrzemiA-BonareK Aleksandra: Metody odkrycia prawdy procesowej przez sędziego w kanonicznym procesie małżeński, Analecta Cracoviensia 48 (2016), s. 313-329, doi: http://dx.doi.org/10.15633/ acr.2029

Del Amo León: Dowody, [w:] Codex Iuris Canonici. Kodeks Prawa Kanonicznego. Komentarz. Powszechne i partykularne ustawodawstwo Kościoła katolickiego. Podstawowe akty polskiego prawa wyznaniowego, red. P. Majer, edycja polska na podstawie wydania hiszpańskiego, Kraków: Lex a Wolters Kluwer business 2011, s. 1147-1190.

GajDa Piotr M.: Sankcje karne w Kościele w świetle Kodeksu Prawa Kanonicznego Jana Pawła II oraz późniejszych uzupełnień i zmian. Studium kanoniczno-pastoralne, Tarnów: Wydawnictwo Diecezji Tarnowskiej Biblos 2008.

Grocholewski Zenon: Struktura etapu dowodowego procesu, [w:] Plenitudo legis dilectio. Księga pamiątkowa dedykowana prof. dr. hab. Bronisławowi Z. Zubertowi OFM z okazji 65. rocznicy urodzin, red. A. Dębiński, E. Szczot, Lublin: Redakcja Wydawnictw KUL 2000, s. 355-378.

KRZYwkowska Justyna, Sztychmiler Ryszard: Adwokat w sprawach o nieważność małżeństwa. Rozwiązania ustawodawcze i ich stosowanie w sądach kościelnych (1983-2019), Olsztyn: Zakład Poligraficzny Uniwersytetu Warmińsko-Mazurskiego w Olsztynie 2018.

Myrcha Marian A.: Dowód ze świadków w procesie kanonicznym, Lublin: Towarzystwo Naukowe KUL 1936.

Pawluk Tadeusz: Prawo kanoniczne według Kodeksu Jana Pawła II, t. IV: Doczesne dobra Kościoła. Sankcje w Kościele. Procesy, Olszyn: Warmińskie Wydawnictwo Diecezjalne 1990.

PIERONEK Tadeusz: Normy ogólne kanonicznego procesu sądowego, cz. I, Warszawa: Akademia Teologii Katolickiej 1970.

SZTYCHMILER Ryszard: Ochrona praw człowieka w normach kanonicznego procesu spornego, Olsztyn: Wydawnictwo Uniwersytetu Warmińsko-Mazurskiego w Olsztynie 2003.

SzTychmiler Ryszard: Rekwizycje sądowe, Biuletyn Stowarzyszenia Kanonistów Polskich 17 (2004), s. $63-82$. 
WóJCICKi Rafał: Znaczenie świadectw kwalifikacyjnych w procesie o stwierdzenie nieważności małżeństwa, [w:] Dowodzenie w procesach kościelnych, red. J. Krzywkowska, R. Sztychmiler, Olsztyn: Zakład Poligraficzny Uniwersytetu Warmińsko-Mazurskiego w Olsztynie 2014, s. 161-170.

\title{
ZDOLNOŚĆ ŚWIADKÓW \\ DO SKŁADANIA ZEZNAŃ PRZED SĄDAMI KOŚCIELNYMI
}

\begin{abstract}
Streszczenie
Ważnym środkiem dowodowym w procesach przed sądem kościelnym są świadkowie. Obowiązkiem świadków jest szczere i zgodne z rzeczywistym stanem rzeczy przedstawianie faktów. Tylko świadkowie prawdomówni przyczyniają się do poznania prawdy. Elementami potwierdzającymi prawdomówność świadków są: wrodzona skłonność mówienia prawdy, dobre świadectwo wiarygodności moralnej, odpowiedzialność kanoniczna za składanie fałszywych zeznań. Czynnikiem negatywnym w odniesieniu do prawdomówności jest skłonność do manipulacji i kłamstw, jak również chęć osiągnięcia własnych korzyści w zamian za fałszywe zeznania. W niniejszym artykule ukazane zostało znaczenie zeznań świadków w procesach o stwierdzenie nieważności małżeństwa, które toczą się przed sądami kościelnymi. Często prawdy o małżeństwie, jego nieważności, nie można udowodnić za pomocą dokumentu, wówczas osiągnięcie prawdy jest możliwe za pomocą zeznań świadków. Świadkowie wzywając imienia Boga przyrzekają mówić całą prawdę i tylko prawdę.
\end{abstract}

Słowa kluczowe: proces o nieważność małżeństwa; audytor; sędzia; świadectwo kwalifikacyjne; prawdomówność

\section{CAPACITY OF WITNESSES TO TESTIFY BEFORE ECCLESIASTICAL COURTS}

\section{Sum mary}

Witnesses are a significant part of evidence in processes before ecclesiastical courts. They are obliged to present facts as truthfully as possible. Only these witnesses contribute to learning the truth. Elements supporting the truthfulness of witnesses are a natural habit of telling the truth, moral credibility, and liability for committing perjury. A negative factor for the truthfulness of witnesses is being of manipulative nature, having tendencies towards falsehood, as well as a willingness for obtaining something to their own advantage in return for perjury. This article presents the significance of witnesses' testimony in the marriage nullity process before ecclesiastical courts. Proving the truth about a marriage and its nullity is often impossible via a document, therefore, it is witnesses testimony that allows learning the truth. Witnesses swear on the name of God to tell the truth and nothing but the truth.

Key words: marriage nullity; auditor; judge, testimonial letter; veracity 